\title{
Et soundtrack til hverdagen - radiobrug og hverdagsliv
}

\author{
Af Bent Steeg Larsen
}

\begin{abstract}
Denne artikel drejer sig om, hvordan radioen indgår $i$ hverdagen, specielt om morgenen. Et hovedsynspunkt er, at man ikke tender for radioen hver morgen for at blive fri for hverdagen, men for at komme ind $i$ den, og den hverdagsagtige brug af radioen er således ikke et sporgsmål om suspension af hverdagen, men om integration af den. Artiklen beskaftiger sig med saivel radioens objektive som subjektive dognrytme. På baggrund af kvantitative data beskrives den objektive dognrytme som monstre i radiolytningen, sådan som den kan afleses $i$ lytterstatistikker og i programfladens typiske sammensetning, mens den subjektive dognrytme, der er baseret på kvalitative studier, beskrives som de måder, man som lytter lever med og oplever radioen $i$ hverdagen.
\end{abstract}

I det følgende fokuseres på noget af det, der foregår på lytternes side af radiohøjtaleren. Det handler om, hvad den ganske almindelige radiolytter bruger radioen til på ganske almindelige hverdage og på det mest almindelige tidspunkt, radioen bliver brugt på, om morgenen.

Artiklen bygger på en interviewundersøgelse fra midten af halvfemserne, hvis formål var at undersøge det, man med en bred betegnelse kan kalde »brugsradioen «. Med brugsradio menes alt det, der ikke er P1, klassisk musik og montage, men derimod alt det radio, der er mest af: DR's P3 og P4 og de store lokalradioer (Voice, Radio Viborg, Radio Randers o.lign.). Over 90\% af al radiolytning, målt i tid, foregår på disse kanaler' .

Brugsradioens udsendelser består typisk af store programflader, som er lavet til mennesker, der laver alt mulig andet samtidig med, at de lytter til radio. Programfladen er populært sagt indrettet på en lytter, der går »til« og »fra«, enten fysisk eller mentalt. Indholdet i brugsradioen består for det meste af en blanding af musik, snak, service og nyheder (samt reklamer). Disse ingredienser er ikke anbragt tilfældigt i programfladen, men optræder med en meget høj grad af regelmæssighed.

De der lytter til brugsradioen, siger at radiolytning er en vane. Man tænder før man tænker, forstået på den måde at det at tænde for radioen hører til den del af hverdagens trivielle handlinger man stort set kører på autopilot - ligesom indkøb, madlavning o.s.v. Det er noget man bare gør, og som man opfatter som noget aldeles selvfølgeligt i dagligdagen. Radioen er noget der »bare er der«.

Radiobrugernes umiddelbare parat-svar på, hvorfor de tænder for radioen, er ofte, at de gerne vil høre nyt fra ind- og udland, så man kan »følge med«. Altså et - sat på spidsen - rationelt, formålsstyret projekt, der handler om at få fyldt noget i 'hovedet'. Når radiobrugerne bliver bedt om at forklare, hvorfor radiobrugen er en så indgroet vane, så peger svarene på, at også er 'kroppen' er involveret. Radiobrugerne taler om, at man »mærker« radioen, at den skaber en god »fornemmelse«, at den er »rar« at have, og at den generelt opleves som en "god ven« i dagligdagen.

I denne artikel vil jeg give nogle bud på, hvad denne »fornemmelse« er for noget. Min indfaldsvinkel er, at det er nødvendigt at undersøge nogle af de ikke-rationelt styrede instrumentaliteter ved radiobrugen for at forstå radiobrugens vanestyrede integration i mange menneskers hverdag. Min måde at gøre det på er at sætte radiobrugen i relation til radiobrugens kontekst, hverdagslivet. Det er der ikke noget nyt i, og i medieforskningen er det efterhånden blevet trivielt at fastslå, at mediebrug er en 'integreret del af hverdagen'. Man kan faktisk gøre sammensmeltningen af mediebrug og hverdagsliv komplet ved at sige, som Roger Silverstone gør det om tv-sening, at mediebrug er hverdagsliv (Silverstone 1989, s. 77, se også Schrøder 1993, s 75).

Det, der er karakteristisk for radiobrugen, er 
også karakteristisk for hverdagen. Hverdagen er også karakteriseret ved rutiniserede aktiviteter og 'tavs viden' i form af handling, der normalt ikke gøres til genstand for egentlig refleksion. Hverdagen er en social og praktisk realitet, og som det vil fremgå i denne artikel, så er en af radiobrugens helt grundlæggende funktioner rutinemæssigt at etablere og vedligeholde denne realitet. Eller sagt med andre ord: Man tænder ikke for radioen for at blive fri for hverdagen, men tværtimod for at komme ind i den: Brugsradio handler om integration, ikke om suspension af hverdagen.

I artiklen vil jeg se på det, man kan kalde for radiobrugens objektive og subjektive døgnrytme. Den objektive døgnrytme beskriver nogle kvantitative kendetegn ved radiobrugen og radioudbudet. Det drejer sig dels om de typiske mønstre i radiobrugen, som kan aflæses i lytterstatistikkerne, og dels om den måde brugsradioens typiske programflade er skruet sammen. Den subjektive døgnrytme er den levede og oplevede rytme med radioen i hverdagen, og som den ovennævnte kvalitative undersøgelse har givet adgang til.

Den kvalitative undersøgelse af radiobrugen, dens metode, respondentsammensætning osv. er fyldigt beskrevet i Larsen (1995, 2000), ligesom dele af analyseresultaterne er hentet herfra. Undersøgelsens respondenter udgjorde ikke et repræsentativt udsnit af alle slags radiolyttere (og ikke-lyttere), så når der i denne artikel tales om radiobrugere, så henviser jeg til de radiobrugerne, der deltog i undersøgelsen, og som er kendetegnet ved, at de lytter regelmæssigt til det, jeg her har kaldt brugsradioen.

\section{Radiobrugen \\ og radioindholdet i tal}

En måde at få overblik over de generelle mønstre i radiolytningen er at se på de såkaldt momentane lyttertal. Momentane lyttertal viser, hvor mange mennesker der lytter til radio på et hvilket som helst tidspunkt i løbet af et døgn (mindste tidsenhed er et kvarter). Hvis man ser på udviklingen i de momentane lyttertal kvarter for kvarter henover et døgn, kan man derfor få et billede af radiobrugens døgnrytme, dvs. hvornår i døgnet der er hhv. mange og få lyttere.

Den overordnede struktur i radiolytningen ser således $\mathrm{ud}^{2}$ : Der lyttes radio i dagtimerne, dvs. fra kl. 6 morgenen til kl. 18.00. Efter 18.00 falder antallet af lyttere brat, og efter kl. 19.00 når antallet af lyttere sjældent over 200.000. Den sparsomme radiolytning om aftenen står i skarp kontrast til radioens absolutte prime time, morgenen, hvor der i tidsrummet 6.00 til 8.00 næsten konstant er ca. 1,6 million mennesker, der lytter. Efter k1.9.00 falder radiolytningen svagt indtil kl. 12.00, hvor DR's middagsradioavis skaber et lille opsving. Fra kl. 13.00 fortsætter det svage fald, og efter kl. 14.00 er der aldrig over 1 million lyttere. Mellem kl. 17.00 og 18.00 er der dog et lille opsving, men derefter falder radiolytningen som nævnt markant.

På lørdage og søndage starter radiobrugen lidt senere, dvs. ca. kl. 8.00 (lidt senere søndag) og når ikke det samme høje niveau om morgenen, som man kan iagttage på hverdage. I weekenden er formiddagslytningen nogenlunde den samme som på de øvrige ugedage, men om eftermiddagen ligger lytningen generelt på et lavere niveau. Ligesom på hverdage falder lytningen til et meget lavt niveau efter kl. ca. 18.00.

Det interessante ved den slags målinger er, at de viser, at den samme lyttestruktur gentager sig fra måling til måling ${ }^{3}$. Strukturen er med andre ord overordentlig forudsigelig og giver et kvantitativt belæg for den regelmæssighed i radiobrugen, som lytterne tilkendegiver i den kvalitative undersøgelse.

At regelmæssighed og brugsradio er to sider af samme sag bliver endnu mere klart, når man ser på brugsradioens programflade. I den følgende korte beskrivelse af brugsradioens programflade vil jeg dels se på, hvad der sendes hvornår, dels fremsætte nogle formodninger om, hvem programmerne er henvendt til. Jeg har valgt at betragte Danmarks Radios P3 som et prototypisk eksempel på, hvordan brugsradioens programmer er tilrettelagt. Min påstand er, at en analyse af en næsten hvilken som helst anden brugsradiokanals programflade ville give samme resultat, hvad angår de helt overordnede fladeorganiserende principper (regularitet, faste slots osv. $)^{4}$.

Kigger vi først på hvor mange udsendelser (med identiske titler, samme varighed og samme placeringer) der er genkommende fra dag til dag i løbet af en uge, så ser man at i tidsrummet mandag-fredag repeteres knap $90 \%$ af programfladen, hvorimod $50 \%$ af programfladen skiftes ud lørdag og søn- 
dag. Det skal forstås på den måde at programfladen stort set er identisk mandag til fredag, men at kun halvdelen af de »faste« programmer fra mandag-fredag optræder i weekendens programflade som så til gengæld har sine egne genkommende programmer. Ser vi på hvor mange af programmerne der er genkommende i programfladen $\mathrm{fra}$ uge til uge, så viser det sig at 99\% af programfladen er identisk. Forstået på den måde at f.eks. onsdagens programflade er så godt som identisk med den foregående onsdags programflade, ligesom lørdagens programflade er identisk med den foregående lørdags programflade o.s.v. Det overordnede mønster i P3's programflade er altså at dagene ligner hinanden fra mandag til fredag, at weekenden er forskellig fra hverdagene, og at denne ugestruktur repeteres i en fast cyklus.

Alle programmer i programfladen er anbragt i nogle faste slots. Hver time indledes med en radioavis, idet fladens tidsstuktur i udpræget grad er styret af klokketiden, d.v.s. tilrettelagt i halv- og heltimesintervaller (f.eks. 3 timers morgenradio, 3 timers formiddagsflade, en halv times middagsradioavis o.s.v. $)^{5}$. Denne tidsstruktur repeteres fra dag til dag og fra uge til uge, og i det perspektiv er selve programmerne i fladen sekundære, - forstået på den måde at tidsstrukturen kommer før selve programmerne, hvis egentlige funktion er at fylde tidsstrukturen ud.

Indholdet og forløbet i den typiske programflade er bygget op på en antagelse om at radiobrugerne befinder sig i forskellige situationer i løbet af døgnet. Om morgenen er der korte nyhedsudsendelser, vejr- og trafikservice for dem der skal ud i vejret og trafikken, musik, lidt interviews og almindeligt godt humør helt ud i titlerne, (» Go'Morgen $\mathrm{P} 3 \ll$ ). Formiddagsfladen er tilrettelagt for den aktive der kan nappe et stykke musik, lidt uforpligtende snak og en quiz i forbifarten. Fladen forsætter i samme stil tidlig eftermiddag, og når børnene kommer hjem fra skole kl. ca. 15.00 er der »Børneradio« for dem. Fra kl. 16.00 er der igen journalistik, musik og underholdning til den voksne der er på vej hjem fra arbejde eller går og sysler i hjemmet. Fra klokken 19.00 bliver radioen smallere og smallere jo længere man når ud på aftenen, og fladen henvender sig typisk til en bestemt målgruppe (unge) og/eller til »fans« af en bestemt musikgenre (folkemusik, etnisk musik, rock).

Strukturen i programfladens flow er altså situationelt organiseret ud fra en mere eller mindre spe- cifik viden om, hvor folk i al almindelighed er på hvilke tidspunkter og hvad de laver. Det er der ikke noget mærkeligt i. Især Paddy Scannells historiske analyser (Scannell 1988) har forlængst tydeliggjort, hvordan de tidsligt organiserede elektroniske medier meget tidligt blev nødt til at tilrettelægge deres udsendelsesaktivitet efter brugernes receptionsomstændigheder for overhovedet at etablere en kommunikativ relation. Eftersom afsender og modtager ikke befinder sig i samme rum, men til gengæld er synkrone i tid, så må afsenderens udsendelse til hver en tid være indrettet på de rum eller situationer, som modtagerne typisk befinder sig i på udsendelsestidspunktet. (Scannell 1988, s. 25ff.).

Hvis vi ser nærmere på, hvad det så er for et prototypisk forløb, den objektive døgnrytme i programfladen er indrettet efter, så er det tætteste, vi kan komme den traditionelle '9-17.00' arbejdsdag. Man antager, at mennesker står op mellem $6.00 \mathrm{og}$ 9.00 (»Go'Morgen P3«), er aktive i og/eller uden for hjemmet fra ca. 9.00 til 16.00, at børnene skal underholdes efter skoletid, og at familien er samlet fra kl. 18.00, hvor man kan dyrke familien (tv) eller sine personlige interesser (radio og/eller tv) ${ }^{6}$. På et meget overordnet plan er strukturen den, at man går fra det meget personlige (søvn) over det private i familien (morgen) til det offentlige (arbejde), hvorefter forløbet gentages i omvendt rækkefølge: Efter arbejdet i 'det offentlige' går man tilbage til privaten $o g$ familien, og sidst på aftenen er man personlig igen.

I et receptionsperspektiv kan man sige, at programfladen positionerer radiobrugeren på en bestemt måde i løbet af døgnet. Positioneringen foregår på et meget overordnet plan, nemlig som en reproduktion af en meget generel struktur, hvor der eksisterer en samfundsmæssig normalpraksis for de 'flestes' tidslige, rumlige og sociale organisering af deres hverdagsliv.

Man skal altid være forsigtig med at udpege eller ophøje en bestemt døgnrytme som f.eks. '9-17' som samfundsmæssig norm. Der er masser af indicier på, at den industrikapitalistiske tidsstruktur med lønarbejde og skarpe skel mellem arbejde og fritid er i opløsning. Der er generelt flere tendenser, der peger på, at 'samfundet' i stigende grad indretter sig på at kunne servicere sine medborgere i det, som nogle har kaldt »The 24 Hour Society« (Kreitzman 1999). Opblødningen af en traditionel opdeling af døgnets og ugens organisering afspejles også i medierne, som i stigende grad står til rådighed døgnet rundt. DR's radiokanaler sender døgnet rundt, de 
fleste tv-kanaler udvider og spreder deres sendetid over hele døgnet, de store aviser har on-linetjenester med løbende opdateringer af nyheder osv. Tendensen går altså i retning af, at mennesker kan leve asynkront og i modtakt med en 'officiel' døgn- og ugeorganisering uden i nævneværdig omfang at blive afskåret fra at blive serviceret og uden at opleve, at man tilhører en minoritet, der afviger fra en samfundsmæssig norm.

Jeg vil dog fastholde, at det er fornuftigt at operere med et begreb om en dominerende traditionel arbejdsdag og -uge, når vi taler om radiobrug $\mathrm{i}$ hverdagen. Brugsradioens programflade er (stadig) indrettet efter, at en sådan tidsmæssig makrostruktur er en realitet, ligesom radiobrugens ekstremt regelmæssige objektive døgnrytme peger på, at der er en struktur 'uden' for selve radiobrugen, der organiserer adfærden. Det, jeg sigter til her, er det forhold, at definitionen af forskellige tidsrums indhold ('arbejdstid', 'fritid' osv.) ikke kun eksisterer i kraft af objektive strukturelle vilkår (f.eks. arbejdstider), men eksisterer som en internaliseret, tidsdisciplinerende norm for, hvad der er 'passende' at gøre på bestemte tidspunkter?.

Det er meget sandsynligt, at yngre generationer i samspil med bl.a. ny teknologi vil bryde væk fra en så 'traditionel' organisering af tiden. Når tendenser til brud fylder så forholdsvis meget i debatter og bøger om fremtiden, så er det, fordi der netop er tale om et brud med en normaltilstand, noget andet end det der aktuelt er den normale praksis. Det skal også i den forbindelse understreges, at hverdagens dominerende tidsstrukturer naturligvis kan forandres. Det, der forandrer sig, er den form for regelmæssighed, man praktiserer, dvs. selve måden, den faste døgnrytme er organiseret på. Selvom det næsten er common sense at sige, at tiden i præ-moderne samfund var cyklisk til forskel fra tiden i moderne samfund, som er lineær/progressiv, så er det en sandhed med meget store modifikationer. Den moderne verdens såkaldt socio-temporale orden ${ }^{8}$ (Zerubavel 1981, s.1) er nemlig kendetegnet ved en meget høj grad af regularitet og en grundlæggende cyklisk organisering. Forskellen fra præ-moderne samfund er, at hverdagslivets tidslige organisering i moderne samfund ikke er funderet på naturlige cykler. Både måneden og året er menneskeskabte modifikationer af et 'oprindeligt' astrologisk forhold, og nok de mest udprægede tidsorganiserende måleenheder i moderne samfund, timen og ugen, er helt og alde- les syntetiske. Selvom livet i moderne samfund bliver mere og mere uafhængige af naturlige cykler, så etablerer mennesket med andre ord nogle andre rytmer, som giver en stor del af hverdagens aktiviteter karakter af gentagelse. Så uanset om mennesket måske opfatter sig selv som hævet over en rigid naturbunden tidsorganisering, så er den naturbundne tidsorganisering erstattet af en mindst lige så rigid tidsorganisering på hverdagsplanet.

Radiobrugens og radioindholdets objektive døgnrytme afspejler en sådan rigid tidsorganisering. Som vi skal se, når jeg i det følgende vil beskrive den subjektive døgnrytme, så er regulariteten $o g$ den faste struktur et vigtigt omdrejningspunkt, når man vil forklare de brugsværdier, der knytter sig til at »høre« radio i modsætning til at »lytte til« radio.

\section{'Høre' og 'lytte' til radioen}

Det siger næsten sig selv, at de ca. 3 timer og 12 minutter, hver voksen over 13 år i gennemsnit lytter til radio, ikke tilbringes med ørerne klinet til højtaleren. Som en radiobruger siger, så kan man »høre det er der«, og en gang imellem skruer man lidt op, når der »endelig er noget vigtigt«. Nogle taler om, at man pludselig »slår flapperne ud, og så begynder man at lytte«, en anden taler om det, »man bare hører« i modsætning til det, man »hæfter sig ved «. Noget »pisker«, »drøner« og »blæser igennem« hovedet, mens noget andet får en til at »spidse ører«.

De forskellige opmærksomhedsstrukturer beskrives ofte med begreberne 'primær' og 'sekundær'. Enten har mediet brugerens fulde opmærksomhed (primær brug), eller også er mediet trængt i baggrunden som akkompagnement til en aktivitet, som brugeren mener er det egentlige forehavende i situationen (sekundær brug) (se f.eks. Crisell 1986:15; Tortzen 1993:180 $)^{9}$.

Den sekundære radiobrug, »høre«-niveauet, er ikke ligegyldigt. Det er det vigtigste niveau, vil jeg påstå, hvis opgaven er at forstå hvorfor radiobrugen er en så indgroet vane for mange radiobrugere. For hvis man spørger radiobrugerne, hvorfor de ikke bare slukker for radioens »baggrundsstøj« om morgenen, så siger de, at så ville der »mangle noget«. En radiobruger fortæller f.eks., hvordan radioen ville mangle $i$ hele »morgenbilledet«, hvis hun skulle glemme at tænde for den. Hvis vi vil vide, hvad dette »noget« og dette »billede« er for 
noget, er det nødvendigt at se nærmere på de brugsværdier, der knytter sig til »høre «-niveauet ${ }^{10}$. Jeg vil dog først opholde mig en lille smule ved »lytte«-niveauet.

De brugsværdier, der knytter sig til »lytte«-niveauet, er de brugsværdier, som radiobrugerne selv umiddelbart fremhæver. Det er de egenskaber ved radioen, som radiobrugerne understreger som særligt velkomne om morgenen, og som handler om det radioindhold, de i meget bred forstand kan bruge til noget, dvs. det de rent faktisk »lytter« efter.

Radiobrugerne er glade for, at radioen hele tiden »fortæller«, hvad klokken er. Enten ved at studieværten siger det, eller ved at jingler på faste tidspunkter i programfladen markerer, at nu er man nået til et bestemt (tids-)punkt i programfladen. Flere radiobrugere fortæller om, hvordan f.eks. en jingle udløser bestemte handlinger (vækker børnene, går i bad, sætter tempoet op o.lign.), alt sammen fordi man er optaget af at overholde tiden. Det er ikke overraskende om morgenen, hvor de fleste er underlagt et tidspres, fordi man skal nå på arbejde, i skole, passe bus- eller togtider osv. For mange radiobrugere er klokketid og radiobrug om morgenen helt simpelt to sider af samme sag, eftersom de bliver vækket af en clockradio.

Radiobrugerne vil også gerne vide noget om det »rum«, de er på vej ud i om morgenen. Radioens nyheder og serviceoplysninger er en måde at få noget at vide om verden 'derude' på, lige fra lokale trafikmeldinger til verdensbegivenheder. At tænde for radioen om morgenen er en slags første pejling ud i det offentlige rum, som det på forskellige niveauer (f.eks. trafik og vejr) er nødvendigt at vide noget om for at kunne agere hensigtsmæssigt.

På »lytte«-niveauet har radioen også nogle sociale funktioner. Her fremhæver radiobrugerne at radioen leverer det i medieforskningen velkendte fænomen, 'social skillemønt'11. Man vil gerne kunne »snakke med«, når man kommer ud til kollegaer o.lign., og i den situation giver dagsaktuel 'offentlig' viden fra f.eks. radioens nyhedsudsendelser adgang til snakken og dermed det sociale fællesskab. Til det formål tjener statsministerens seneste bommert, stigende benzinpriser, vejret osv. meget bedre end alt for private oplevelser, der potentielt kan true definitionen af situationen, som er kollegial eller venskabeligt samvær.

Det næste niveau, »høre«-niveauet, handler om radiobrugens mere implicitte brugsværdier. Brugs- værdierne knytter sig i højere grad til den upåagtede handlen eller praksis, som er karakteristisk for hverdagslivet ${ }^{12}$.

Som jeg nævnte før, så er radioens konkrete klokketidsangivelser et velkomment element i radiobrugernes morgensituation. Klokketidens markante tilstedeværelse i programfladen er imidlertid også noget, man mærker eller fornemmer. Radioens regelmæssighed, udsendelsens musik, tempo og stil (f.eks.jinglernes udformning og studieværtens stemmeføring, toneleje osv.) udsender en særlig 'puls' eller 'takt' i det rum, som radiobrugere befinder sig i om morgenen. Med sin blotte tilstedeværelse, dvs. den kontinuerlige lyd, introducerer radioen den kvantitative standardtid som den 'gældende' puls til forskel fra den u-differentierede 'varen', som især kendetegner søvntilstanden. Når den klokketidsbaserede puls er så velkommen hos radiobrugere om morgenen, så er det fordi den harmonerer med den tidsmæssige præmis, man er nødt til at fungere på i hverdagen, nemlig klokketiden.

Når jeg før sagde, at radioens nyheder er manges første 'pejling' ud i det offentlige rum, de er på vej til at bevæge sig ud i, så kan man anskue det på den måde, at radiobrugerne blander et lille stykke offentlig rum ind i deres private rum om morgenen. På »høre«-niveauet kan man sige, at det, der er fælles for radiobrugerne, er, at de gerne vil have det private og det offentlige til at konvergere på en passende måde. Radioens blotte tilstedeværelse med sin kontinuerlige og 'offentlige' lyd er med til at transformere radiobrugerens private rum til et rum med en videnshorisont, der rækker ud over det konkrete, private hjem. Verden bliver lidt større (den er mere end 'min'), og radioens kontinuerlige lyd er en konstant og velkommen påmindelse om det. Radiobrugernes kanalpræferencer justerer så denne horisont i forhold til, hvor meget radiobrugerne i bogstaveligste forstand kan rumme på dette tidspunkt af dagen. Radiobrugen medvirker til, at man som radiobruger (gen-) finder sin position i forhold til en verden, der ligger uden for det private hjem, og som man - uanset hvad - må ud og indtage sin plads i hver dag.

Heri ligger også radioens sociale funktion på »høre«-niveau, nemlig at radioen med sin 'snak' introducerer en fælles verden om morgenen og dermed den sociale præmis, man skal fungere på i hverdagen. Ved at tænde for radioen om morgenen bliver man ført over i denne (uundgåelige) sociale hverdagsverden. 


\section{Hverdagsliv og relevans}

Når jeg skal sammenfatte de ovenstående funktioner, så vil jeg inddrage nogle af begreberne fra Alfred Schütz' hverdagslivsteori og særligt den del af den, hvor han beskæftiger sig med begrebet relevansstruktur.

Hverdagslivet er, siger Schütz, ikke noget, der foregår $\mathrm{i}$ et bestemt tidsrum eller på et bestemt sted, men en særlig verden, der bliver virkelig ved, at man besidder en særlig bevidsthed, den såkaldte »naturlige indstilling« (Schütz og Luckmann 1973, s. 3ff.). At være i den naturlige indstilling betyder, at man ikke tvivler på, at verden er virkelig, men at man tværtimod genkender fænomener og begivenheder som uproblematiske og selvfølgelige.

Hverdagslivets verden er én blandt andre subjektivt konstituerede virkeligheder (f.eks. fantasiens eller den videnskabelige tænknings verden). Men hverdagslivets verden er den fundamentale, altoverskyggende virkelighed (Schütz og Luckmann 1973 s.3 og 6), fordi det er i den naturlige indstilling, at verden fremtræder som en konkret, objektiv realitet, som man med sine kropsbevægelser kan gribe ind i og manipulere. Hverdagslivets verden er med andre ord en praksis-verden, hvor man i bogstaveligste forstand 'handler': Man kan ikke dagdrømme sig til brød på bordet, men må træde over i hverdagslivets verden og tjene til føden dér.

I den naturlige indstilling rummes ens forståelse af verden i et videnslager. Dette videnslager består både af egne erfaringer og overleveret viden og fungerer som et referenceskema, som man løbende 'tolker' begivenheder og fænomener i hverdagen med. Videnslageret er bygget op omkring typikaliteter, dvs. en viden om, hvad der typisk kendetegner en lang række handlingsforløb eller genstande.

Videnslagerets funktion er at give verden karakter af en konstant struktur. Så længe ens videnslager ikke modsiges, så verificeres videnslageret, og man kan stole på sine tidligere erfaringers indhold og forudsige fremtidige handlingers forløb. Effekten er at man bevarer evnen til formålsorienteret handling i hverdagen, dvs. kan afmærke store områder af hverdagen som noget, man kan tage for givet, og som ikke hele tiden giver anledning til refleksive afbrydelser.

Hvad der er relevant at vide, dvs. den del af videnslageret, som så at sige er aktiveret, er afhængig af den situation, man aktuelt befinder sig i. Det, der er selv-evident i én situation, er det ikke i en anden situation og behøver en aktiv, refleksiv indsats for at blive forklaret.

Schütz siger, at vores interesse i hverdagslivet grundlæggende er selektiv. Når man er i den naturlige indstilling, selekterer man de genstande, begivenheder og forløb, som har størst relevans i forhold til den situation, man befinder sig i og det projekt, man har planer om at udføre (Schütz 1973b, s. 227).

Schütz siger altså, at personens relevanssystem ikke er konstant eller fikseret, men varierer fra situation til situation. Relevansstrukturen på et givent tidspunkt er en kombination af personens autobiografiske situation (dvs. personens 'unikke' videnslager), personens projekt (aktørens anticiperede resultat af sine handlinger og dermed det mål eller den hensigt, som motiverer aktørens adfærd), samt de tidslige, rumlige og sociale betingelser, der gør sig gældende i den givne situation (relativt afgrænsede forløb, hvor en eller flere aktører udfører en handling).

De brugsværdier, radiobrugerne fremhæver, er helt indlysende betinget af den situation, radiobrugen forekommer i. Denne situation, morgenen, rummer en række tidslige, rumlige og sociale betingelser, som organiserer radiobrugernes adfærd, og som radiobrugen er en del af. Den tidslige betingelse er, at man skal nå noget - typisk overholde en bestemt mødetid. Den rumlige betingelse er, at man skal bevæge sig fra hjemmet og ud i 'virkeligheden'. Den sociale betingelse er, at man helt grundlæggende skal indstille sig på at leve og fungere sammen med andre mennesker. Denne situations karakteristika udspringer naturligvis af, at man skal fra søvnen og ind den sociale virkelighed, og at denne situation gentager sig fra dag til dag.

Radiobrugernes projekt om morgenen er at gennemføre disse (nødvendige) overgange fra søvn til vågen $\mathrm{o}$ fra en privat tilstand til en social og pragmatisk indstilling over for virkeligheden. Der er tale om en slags 'professionaliseringsproces', som er betinget af, at den forestående hverdag kræver, at man $i$ et eller andet omfang skal gøre sig arbejdsdygtig i ordets allerbredeste betydning. Radiobrugerne inddrager radioen i dette projekt. Projektet er ikke afhængig af radioen, men radioen har nogle karakteristika, der gør mediet særligt egnet til at medvirke i dette projekt. Den kvantitative puls, den offentlige diskurs, og de socialt integrerende informationer i 
radioen integreres i morgenens rutiner og er med til at facilitere disse overgange.

Min pointe er, at radiobrugerne anvender radioen til at etablere en særlig relevansstruktur om morgenen. Radioen afmærker et særligt udsnit af virkeligheden som 'hverdag' forstået på den måde, at radioen lukker hverdagen ind i radiobrugernes private sfære og »framer « radiobrugerens virkelighedsoplevelse, så verden konstitueres som et handlingsunivers. Man kan sige det på den måde, at radiobrugere institutionaliserer hverdagen hver morgen med radioen. Radioen sørger for, at hverdagen 'melder sig' som en genkendelig og stabil struktur.

På et meget generelt niveau kan man tale om at radiobrugerne åbner for radioen om morgenen fordi de gerne vil tiltales på en måde der bringer dem over i en handledygtig aktørstatus. Det kan gøres på forskellige måder (kontant med masser af »god morgen« og trafikservice, eller mere indfølende med f.eks. klassisk musik som måske etablerer en mere "genfødselsagtig« overgang). Radiobrugen om morgenen er derfor ikke en suspension eller udhævning af hverdagen. Det forholder sig lige omvendt. Radiobrugen er en måde at komme ind i hverdagen på. Radiobrugen er både en indslusning i og en etablering af hverdagen som et handlingsfelt ${ }^{13}$.

\section{Radiobrugens regelmassighed}

Et gennemgående træk i undersøgelsen var, at flere radiobrugere anvendte en slags maskinmetaforik til at beskrive radioens tilstedeværelse i deres hverdag. En radiobruger siger f.eks., at han tænder for radioen for at »fà det hele til at sætte i gang«. Han taler om, at han skal have sat sin hjerne i »omdrejninger« på samme måde som en anden radiobruger taler om, at han skal have dagen til at »starte«, og at man skal »lade op« til den. Han betragter radioen som en »ven « om morgenen, og det venskabelige ved radioen kan tolkes på den måde, at radioen er en pålidelig, genkommende og kontinuerlig ingrediens i hans morgen: Radioen »kværner«, uanset om han lytter efter eller ej. Jeg vil hævde at der er en parallel mellem det meget forudsigelige og næsten mekanisk repeterede programudbud i radioen og den indstilling til verden, som mange radiobrugere siger, de gerne vil bringes i om morgenen. Det er den (naturlige) indstilling, hvor man kan tage store dele af verden for givet, og hvor verden »kører' på den samme, forudsigelige måde. Som en anden respondent udtrykker det, så »ligner [de] jo hinanden, alle de morgener«. Min pointe er, at det gør de kun, fordi man gerne vil have, at de ligner hinanden.

En af måderne at få morgenerne til at ligne hinanden på er ved at tænde for den samme radiokanal hver eneste morgen. For der er som bekendt en overordentlig stor sandsynlighed for, at radioudsendelserne »ligner hinanden« fra dag til dag. Maskinmetaforikken udtrykker derfor den grad af mekanisering eller automatisering, radiobrugerne gerne vil have implementeret i hverdagen. Jo mere 'automatisk' og selvkørende hverdagen forekommer, desto mere aflastning for radiobrugerens bevidsthed, som ikke skal bruge mental energi på at etablere hverdagen som et overskueligt handlingsfelt. Radioen projicer med andre ord noget objektivt ind i den meget private og subjektive tilstand, som radiobrugeren befinder sig i om morgenen.

Hvad er så forklaringen på, at dele af mediebrugen inddrages i en bestræbelse på at give hverdagen en sådan repetitiv, cyklisk karakter? På et eksistentielt niveau kan man sige, at medieudbudet netop er tilrettelagt efter menneskers helt fundamentale behov for at organisere deres hverdag som en genkendelig struktur, der aflaster bevidstheden og sætter kompleksiteten ned. På det helt dybe eksistentielle niveau skyldes regulariteten, at hverdagen ikke rummer indikationer på progression, og at periode- eller epokeplanet, og dermed menneskets forgængelighed, derfor udgrænses af hverdagsbevidstheden.

Samtidig er det et eksistentielt menneskeligt træk at ville opleve diversitet. Ud fra en kvantitativ betragtning er ugens dage nøjagtig ens, men de fremtræder forskelligt for mennesket (jf. Zerubavel 1985, s.108). Pointen er, at ethvert kalendermæssigt 'indgreb' i det ellers kontinuerlige, u-differentierede flow af tid er et resultat af et fundamentalt menneskeligt behov for at opleve kvalitative forskelle, som naturen ikke skaber eller rummer i sig selv (Zerubavel 1985, s. 134). En kultur vil altid etablere forskellige former for tidsmæssig diskontinuitet på en sådan måde, at tiden ikke virker som en u-differentieret og forskelsløs progression, men derimod som en relativt regulariseret bevægelse mellem det 'ordinære' og det 'ekstraordinære'. Dette behov for diversitet er bygget ind i mediernes udbud. Mest markant i weekenden, hvor programindholdet adskiller sig meget fra programlægningen de øvrige 
ugedage. Det er imidlertid vigtigt, at diversiteten er sat i system. Diversiteten er med andre ord indlejret i en cyklisk struktur, der som nævnt sørger for at reducere kompleksiteten.

På et samfundsmæssigt niveau kan man forklare den regelmæssige radiobrug som et redskab til at 'overvinde' en stigende anonymisering, der kan være forbundet med moderne samfunds indretning. Det skal forstås på den måde, at medierne hver eneste dag reproducerer en relativt stabil struktur, som man som mediebruger så at sige bliver lukket ind i. Man kan også udelukke den. Det væsentligste er, at den er der. Medierne findes som en genkommende og stramt struktureret kendsgerning, der transmitterer den officielle døgnrytme ind $\mathrm{i}$ brugerens private liv. Mediebrugeren kan konstituere den døgnrytme med medierne, som han eller hun vil, og den kan udmærket være i modtakt med det officielle Danmarks objektive døgnrytme. Pointen er, at der er en struktur at relatere til, og det er dét, at den findes, der er selve attraktionen for brugeren. Modernitetsanalyser, som f.eks. Giddens' (1990, 1991) fremhæver, at sociale relationer i moderne samfund er løsnet fra konkret tid og sted, og at aftraditionaliseringen ikke automatisk giver hverdagen en social struktur. Som sagt er det en struktur, som løbende skal etableres. Medierne kan medvirke til at skabe en sådan struktur. Det særlige ved denne struktur er, at den i kraft af mediernes regelmæssighed fremtræder som objektiv og som en slags indikation på en normalitet. Når radiobrugerne i denne undersøgelse siger, at de »mærker « radioen, så er det, de mærker, en eller anden form for stabilitet og fast, social orden i hverdagen. Man kan være enig eller uenig og i med- eller modtakt med denne sociale orden, men den spiller en rolle som indikation på, at der rent faktisk er en struktur, der er større og 'uden for' en selv, men som man, uanset om man vil det eller ej, er en del af.

I det perspektiv kan man sige at radiobrugen er med til at håndtere et permanent socialiseringsbehov, jf. Giddens' teori om identitetsdannelsens refleksive og kontinuerlige karakter i moderne samfund (Giddens 1990, 1991). Min formodning er at medierne bruges som en måde at håndtere dette permanente socialiseringsbehov på. Ved at bruge medierne bliver verden bygget op som en fast, genkendelig struktur og det er denne struktur man som mediebruger så og sige »underkaster« sig hver eneste dag, fordi det er denne struktur der gør at man finder og genfinder den identitet man kan hævde sig med i hverdagen.

Det kan afslutningsvis forklares ved at parafrasere det klassiske uses and gratification spørgsmål: Er det medierne der gør noget ved subjekterne, eller er det subjekterne der gør noget ved medierne? Min udlægning vil være: Det er subjekterne der lader medierne gøre noget ved sig.

\section{Noter}

1. Ifølge DR's programregnskab fra 2000 var fordelingen således: P1 6\%, P2/DR Klassisk 3\%, P3 23\%, P4 33\%, al lokalradio (inkl. udenlandsk radio) $35 \%$. Den gennemsnitlige lyttetid pr. voksen pr. dag var ca. 3 timer og 12 minutter.

2. Lyttertalene er indsamlet af Gallup og er venligst stillet til rådighed af Danmarks Radios Medieforskning. De kvantitative data, der er omtalt i denne artikel, stammer fra 1999, og jeg tager derfor forbehold for ændringer i både lyttestrukturen henover døgnet og i det programudbud, jeg refererer til. Selvom de kvalitative og de kvantitative data, der refereres til i denne undersøgelse, stammer fra forskellige perioder, (hhv. 1995 og 1999) så udgør det ikke et problem, eftersom mit ærinde er at belyse de generelle træk og mønstre i radiobrugen og-udbudet. Inden for den 4 års periode data stammer fra, er der på det generelle plan kun sket meget få forandringer.

3. Undersøgelser af denne type, dvs. dagbogsregistreringer af radiolytningen kvarter for kvarter, er gennemført i Danmark siden 1991, og den generelle struktur i den rapporterede lytning er meget stabil. Man ville naturligvis konstatere større forskelle, hvis man valgte at undersøge brugsmønstrene over en længere periode (se f.eks. Dahl 1991). Det er imidlertid et forskningsfelt for sig, og jeg afgrænser mig i denne artikel til nutiden, dvs. virkeligheden i anden halvdel af 1990erne.

4. Jeg vil med det samme slå fast, at analysen af P3's programflade er baseret på en ikke-repræsentativ stikprøve. Derfor skal resultaterne, og især tallene, tages med et stort gran salt. Min formodning er dog, at en systematisk, repræsentativ undersøgelse vil konstatere de samme strukturelle forhold, som jeg fremhæver her. 
Stikprøven består af en analyse af det samlede udbud i Danmarks Radios P3, i uge 6 og 7 i 1997, begge perioder uden særlige 'Media Events', der lejlighedsvis kan ændre programfladen. En tilsvarende analyse af P3's programflade i de samme uger i 1999 er blevet gennemført, dels for at sikre mod at resulatet fra 1997 beror på tilfældigheder, og dels for at kunne konstatere evt. forandringer. Denne analyse viste, at der ikke er sket de store forandringer i progamfladen i perioden 1997 - 1999.

5. I 2000 justerede DR dele af P3's programflade, og fjernede bl.a. middagsradioavisen $\mathrm{kl}$. 12.00. Den programflade jeg refererer til i denne artikel er fra 1997/1999 (se note ovenfor), og jeg tager derfor, som nævnt, forbehold for forandringer. Et kig på P3's nye programflade henover ugen viser dog at tendensen til regularitet er forstærket. F.eks. er aftenfladen blevet mere ensartet henover ugen.

6. Tv ligger uden for denne artikels rammer, men ser man på fjernsynets objektive døgnrytme, så er brugen helt overvejende koncentreret om aftenen, hvor en af de første nyhedsudsendelser på DR eller Tv2 (hhv. 18.30 og 19.00) for manges vedkommende indleder en aften med tv, som strækker sig til ca. 23.00. Morgen- og dagsening er relativ ubetydelig sammenlignet med aftensening. Når vi taler om radio og fjensyn, som begge er organiseret i tid, så kan man derfor sige, at de deler døgnet mellem sig, således at radioen fungerer $\mathrm{i}$ den (traditionelt) 'aktive' del af dagen med prime time om morgenen, og fjernsynet fungerer i den (traditionelt) 'rekreative' del af dagen med prime time om aftenen. Indholdet i fjernsynets aftenflade begynder med familievenlig underholdning (dyr, quiz og leg, film, gør det selv o.lign), og jo længere man kommer ud på aftenen, desto mere specialiseret bliver programfladen, idet familiemålgruppen skiftes ud med et voksent publikum med særlige interesser (krimi, sport, dokumentar om sex o.lign.).

7. Jf. Berger og Luckmann (1966/1972). Som den engelske historiker E.P. Thompson påpeger, så er den del af den hverdagslige tidsdisciplinering - som ikke følger en naturlig nødvendighed knyttet til en puritansk etik, som blev forstærket med den industrikapitalistiske klokketidsbaserede organisering af arbejdet (E.P. Thompson 1967/1991:390ff.). Det er nogenlunde det sam- me, Max Weber er inde på, når han siger, at trods de indholdsmæssige forskelle på den protestantiske etiks værdirationalitet og kapitalistiske ånds målrationalitet, så har de samme handlingsmæssige konsekvenser (Weber 1985).

8. Zerubavel skelner mellem tre grundlæggende former for temporale mønstre: "physiotemporal patterns« (tidslige strukturer i fysiske fænomener i naturen), »biotemporal patterns« (levende organismers tidsstrukturer) og $\gg s o-$ ciotemporal patterns« (det sociale livs tidslige strukturer) (Zerubavel 1981:1f.).

9. Som Åberg (1999) helt rigtigt påpeger, så kan der være behov for endnu en kategori, nemlig mediebrug som en "parallel« aktivitet (Åberg 1999:77). Mediebrug som parallel aktivitet betegner den type brug, hvor man regelmæssigt, men ikke konstant, retter sin opmærksomhed mod mediet, og er således en mellemposition mellem den primære (opmærksomme) brug og den sekundære (overvejende uopmærksomme brug).

10. En mere udfoldet beskrivelse af forskellen på at »høre« og »lytte« til radio findes i Larsen 1997, hvor de to opmærksomhedsnivauer undersøges i relation til Alfred Schütz' hverdagslivsteori.

11. Se f.eks. Jensen (1995:80ff.).

12. Jf. Giddens' skelnen mellem praktisk og diskursiv bevidsthed (Giddens 1984).

13. Se Larsen 1988 hvor begrebet »definition af situation « inddrages til at beskrive mediernes rolle i hverdagen. Hovedidéen der introduceres her er at medier bliver brugt til at definere situationer med, og at mediebrugen derigennem medvirker til at give hverdagen en episodisk struktur og dermed en adfærdsregulerende rolle. Begrebet anvendes med afsæt i W.I. Thomas' teorem og Goffmans udvikling af det i Frame Analysis (1974).

\section{Litteratur}

Berger, Peter L. \& Thomas Luckmann (1966/ 1972). The Social Construction of Reality. A Treatise in the Sociology of Knowledge. London: Penguin Books.

Crisell, Andrew (1986). Understanding Radio. London: Methuen.

Dahl, Henrik (1991). »Danmarks Radio - mellem enhedskultur og pluralisme«. I MedieKultur nr. 15. 
Giddens, Anthony (1984). The Constitution of Society. Cornwall: Polity Press.

Goffman, Erving (1974). Frame Analysis. An Esseay on the Organization of Experience. Pennsylvania: Northeastern University Press.

Jensen, Klaus Bruhn (1995) The Social Semiotics of Mass Communication. Cambridge: Sage.

Larsen, Bent Steeg (1995). Lyden af hverdag. En undersøgelse af radiobrug og hverdagsliv. Speciale. Københavns Universitet.

Larsen, Bent Steeg (1997). »Hearing and listening to the radio in everyday life«. Paper til Den 13. Konferensen För Masskommunikationsforskning, Jyväskylä, august 1997.

Larsen, Bent Steeg (1998). »Media Situations. A Situational View on Media Use in Everyday Life«. In Sekvens 98, Dept of Film and Media Studies: Audiovisual Media in Transition, Copenhagen: University of Copenhagen.

Larsen, Bent Steeg (2000). »Medier til hverdag«. Ph.d. afhandling. Københavns Universitet.

Scannell, Paddy (1988). »Radio Times: The Temporal Arrangements of Broadcasting in the Modern World«. I P. Drummond \& R. Patterson (red.): Television and its Audience. London: British Film Institute.

Schrøder, Kim (1993). »Den etnografiske bølge og receptionsforskningen«. I MedieKultur nr. 21.

Schütz, Alfred (1970). Reflections on the Problem of Relevance. USA: Yale University Press.
Schütz, Alfred \& Thomas Luckmann (1973). The Structures of the Life World, Norwich: Heinemann Educational Books Ltd.

Silverstone, Roger (1989). »Let us then return to the murmuring of everyday practices«. I Media, Culture and Society, Nr. 1.

Thompson, E.P. (1967/1991). »Time, Work-Discipline and Industrial Capitalism«. I Thompson (red.) Costums in Common. Kent: The Merlin Press.

Tortzen, Anne (1993). »Radioen i de unges hverdagsliv«. I Medieforskning i Danmarks Radio 1992. Nr. 4B/93. København: Danmarks Radio.

Weber, Max (1985). The Protestant Ethic and the Spirit of Capitalism. London: Counterpoint.

Zerubavel, Eviatar (1981). Hidden Rythms. Schedules and Calendars in Social Life. USA: University of California Press.

Zerubavel, Eviatar (1985). The Seven Day Circle. The History and Meaning of the Week. New York: Free Press.

Åberg, Carin (1999). The Sound of Radio. On Radio as an auditive means of communication. Department of Journalism, Media and Communication, Stockholm University.

Bent Steeg Larsen er ph.d. og ansat i Politikens Hus. 